\title{
Effects of Sedimentation on Small Reservoirs in the Mushibemba Catchment, Mkushi Farm Block, Central Zambia
}

\author{
Goodfellow Mphande ${ }^{1} \&$ Henry M. Sichingabula ${ }^{2}$ \\ ${ }^{1}$ IWRM Centre, Geology Department, School of Mines, University of Zambia, Zambia \\ ${ }^{2}$ Department of Geography and Environmental Studies, School of Natural Sciences, University of Zambia, Lusaka, \\ Zambia \\ Correspondence: Goodfellow Mphande, IWRM Centre, Geology Department, School of Mines, University of \\ Zambia, Lusaka, Zambia. E-mail: mphande_goodfellow@yahoo.com/sichingabula@unza.zm
}

Received: January 19, 2019

Accepted: February 4, 2019 Online Published: February 28, 2019

doi:10.5539/jgg.v11n1p55

URL: https://doi.org/10.5539/jgg.v11n1p55

\begin{abstract}
Sedimentation is one of the problems that affects the storage capacity of most small reservoirs, and if not addressed on time it may lead to the dams being filled up with sediment. The aim of this study was to assess the effects of sedimentation on the storage capacity losses of Moffat dam and GRZ Weir located in the Mushibemba Catchment of Mkushi Farm Block, Central Zambia. The method used to understand reservoir storage capacity loss was bathymetry survey using the hydrographic survey boat (RC-S2) which consists of an echo sounder and a Differential GPS. Information on the initial storage capacity of the two reservoirs was obtained from the Water Resources Management Authority (WARMA). The analysis of the data revealed that the measured volumes of Moffat dam and GRZ Weir were 1,180,462 $\mathrm{m}^{3}$ and $197,218 \mathrm{~m}^{3}$, respectively. The estimated storage capacity losses for Moffat reservoir was found to be $223,789 \mathrm{~m}^{3}$ and $53,312 \mathrm{~m}^{3}$ for the GRZ Weir. The estimated rates of sedimentation loss were found to be 13,986.81 $\mathrm{m}^{3} \mathrm{yr}^{-1}$ (Moffat reservoir), with a lifespan of 84 years, and 1,480.89 $\mathrm{m}^{3} \mathrm{yr}^{-1}$ (GRZ Weir) with a lifespan of 133 years. The source of the accumulated sediment was mainly attributed to originate from the cleared commercial agricultural land which predominantly consists of clayey to loamy soils. This also accounted for the high turbidity of the reservoir water. This situation therefore calls for periodic dredging of the deposited sediment to increase reservoir storage capacity.
\end{abstract}

Keywords: Bathymetry survey, Reservoir storage capacity, Sedimentation, Suspended sediment

\section{Introduction}

Sedimentation has been defined by Martinko, Denoyelles \& Jakubauskas (2006) as particulate matter that can be transported by fluid flow and eventually is deposited as a layer of solid particles on the bed or bottom of a water body such as reservoirs. Johnson \& Lewis (1995) argue that in many developing countries sustainable land management and water resources development are threatened by soil erosion and sediment-related problems. In Zambia, Sichingabula (1997) reported that the seriousness of soil erosion and sedimentation in small dams in Southern Province and parts of Lusaka Province was due to increased human and cattle population and the existence of large cultivated areas in catchment areas. Furthermore, Chomba \& Sichingabula (2015) argued that, lack of adequate soil erosion/sediment control measures at the catchment scale had been attributed to be one of the factors contributing to high reservoir sedimentation in the Eastern part of Lusaka Province.

Sedimentation is one of the problems that affects the storage capacity of most small reservoirs and if not addressed on time, it may lead to the dams being filled up with sediment and failing to meet the intended objectives of providing agricultural water for food and economic security.

In the last two decades, the Mushibemba river catchment of the Mkushi farm block in Central Province of Zambia had a number of reservoirs constructed by farmers to meet increased irrigation water demand. According to the Water Resources Management Authority (WARMA) database in Zambia, Mushibemba catchment had a total of 58 reservoirs (WARMA, 2016). However, the reservoirs in the Mushibemba catchment had never had appropriate bathymetric surveys to determine their storage capacities. The only known appropriate assessments that were conducted in Zambia to measure the effects of sedimentation on reservoir storage capacity were those done on small dams in Lusaka province by Chomba \& Sichingabula (2015) while Sichingabula (1997) using regression 
approach reported that many dams had lost considerable storage capacity due to sedimentation. According to Brandan, Caporali, \& Federici (2006), reservoir sedimentation is a big problem as it affects the water storage capacity if adequate sediment management policies are not available and applied. This called for detailed investigation on the effects of sedimentation in central Zambia. It was on this basis that this study was embarked upon to examine the effects of sedimentation on reservoir storage capacity in Mushibemba catchment.

\section{Study Area}

\subsection{Location}

This study was undertaken in the Mushibemba river catchment, a sub-catchment of the Lunsemfwa River located in the Mkushi Farm Block of Mkushi district in Central Province of Zambia (Figure 1). The Lunsemfwa River catchment is a sub-catchment of the Luangwa river system. Mkushi district is situated about 293 kilometers away from Lusaka, Zambia's capital city. The total surface area for Mushibemba Catchment is $995 \mathrm{~km}^{2}$ while the reservoir catchment areas for Moffat dam and GRZ weir were $42.5 \mathrm{~km}^{2}$ and $25.4 \mathrm{~km}^{2}$, respectively.

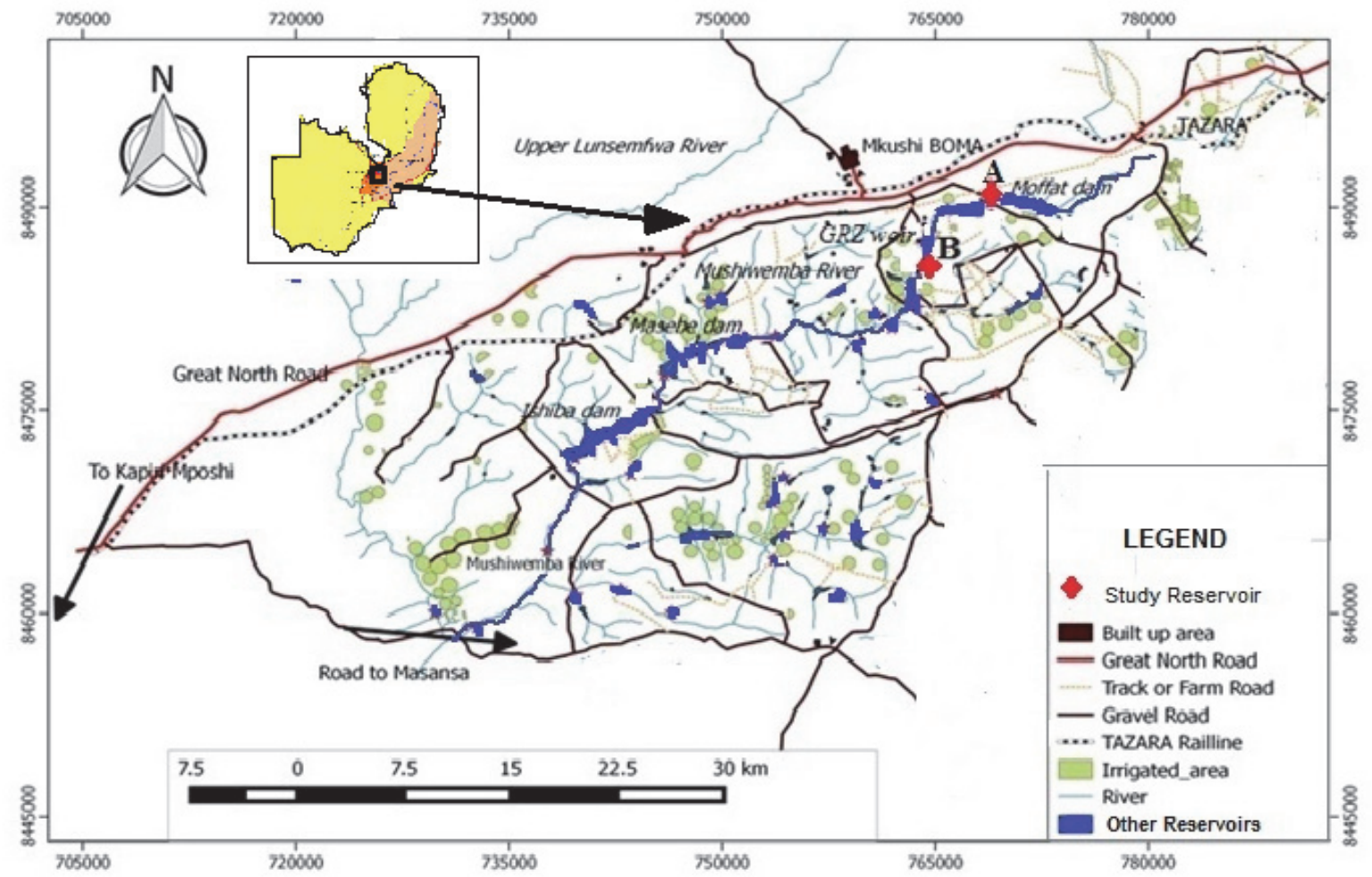

Figure 1. Location of Moffat Dam and GRZ Weir in the Mushibemba catchment, Mkushi District

\subsection{Physical Characteristics}

The physical characteristics of the study area focus on details of the climate (temperature and rainfall), hydrology, wind, geology, topography, soils and vegetation.

The climate of Mkushi district is described in terms of temperature and rainfall in the area. The temperatures in Mushibemba catchment do not deviate significantly from the national average, with a minimum temperature of $7.5^{\circ} \mathrm{C}$ experienced in the month of July and maximum of $30.3^{\circ} \mathrm{C}$ in the month of October. The Mushibemba river catchment and its surrounding areas, receive $1100 \mathrm{~mm}$ as annual rainfall (November-April), which slightly exceeds the range for the Agro Ecological region II (Figure 2). This amount is received over an average period of 103 days (JICA, 1995). 


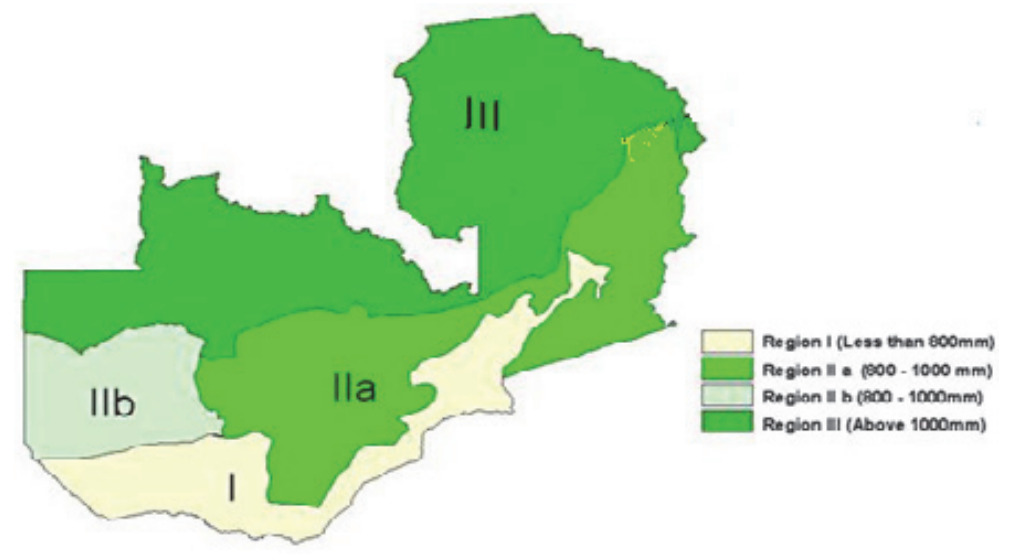

Figure 2. Agro-ecological regions of Zambia. Modified from Zambia Meteorological Department (2004).

The drainage system of the study area is composed of narrow main rivers with small tributaries and numerous extensive valley bottom wetlands (dambos). The prominent river located in the study area is the Mushibemba, a perennial tributary of the Lunsemfwa River. The elevation in the Mushibemba catchment ranges from 1,380 m.a.s.1 at the source of Mushibemba River to 1,280 $\mathrm{m}$ at the confluence of the Lunsemfwa River. The river has gentle slopes which lead to the drop in the velocity and turbulence of the water thereby reducing the potential to erode the river channel. The Mushibemba river catchment has the highest number of reservoirs in the Mkushi Farm Block. Flow records on Mushibemba are not available because the river is not gauged.

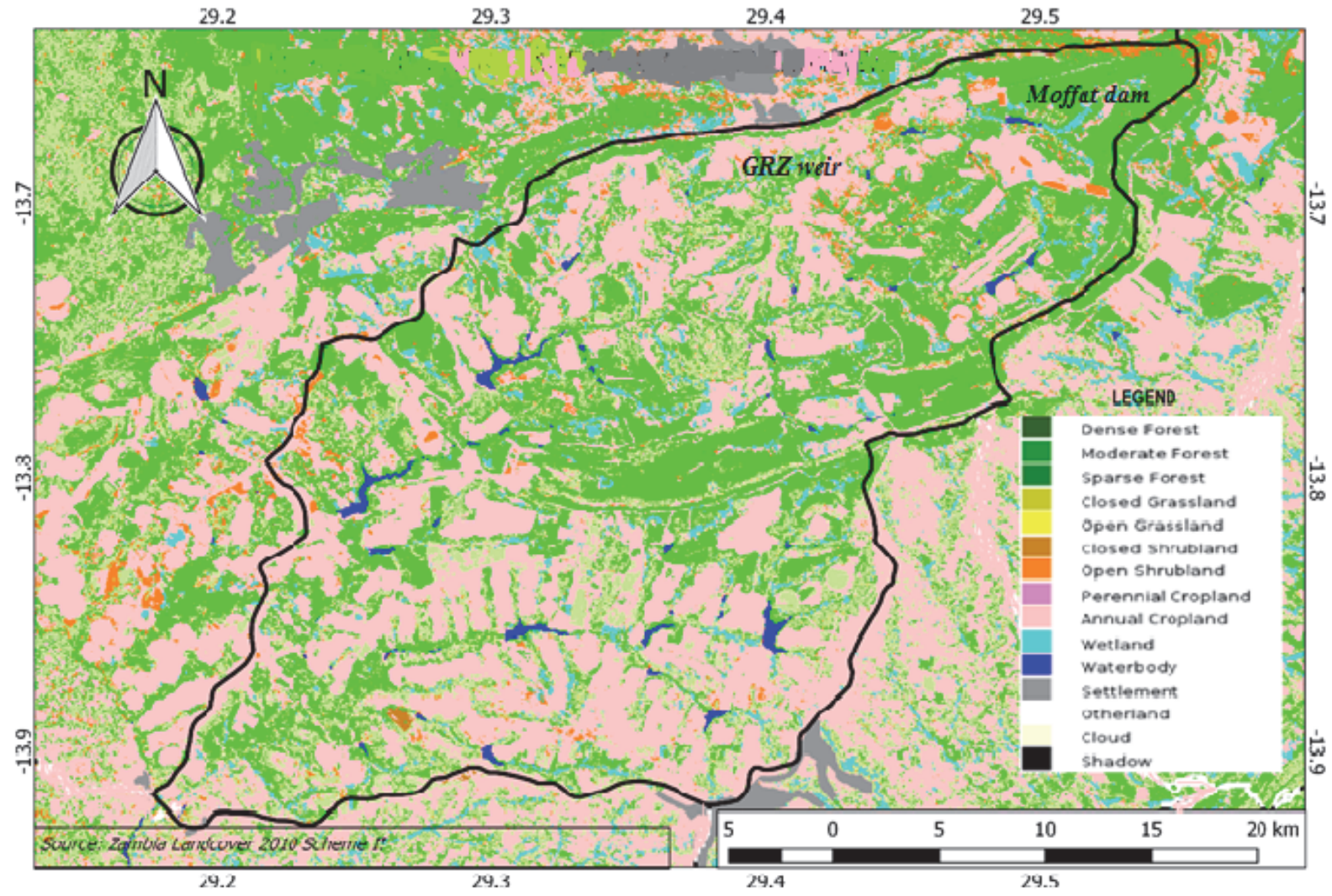

Figure 3. Land Classification of Mushibemba Catchment.

The predominant rock type of the study area is gabbro, white gneisses and granites. In terms of agriculture, the gneisses and granites are important because the light sandy soils derived from them are ideal for commercial farming (Stillman, 1965). Most of the agricultural activities are done along the Mushibemba river and its tributary 
streams. The soils are fertile, especially that they are alluvial deposited annually during flood periods. The vegetation type of the Mushibemba river catchment can best be described as miombo woodland with some grasslands in areas that get flooded during the rainy season. The source of Moffat dam mainly comprises moderate forest with a mixture of closed and open grassland along the river course (Figure 3). Areas without vegetation were mainly cleared for crop cultivation by the commercial farmers.

The population of Mkushi district in 2010 was estimated at 151,803 (CSO, 2010). Using the 2010 Central Statistics Office (CSO) population growth rate of 3.5 percent, the population of Mkushi district in the year 2018 was estimated at 194,308. The district was reported to have recorded the highest annual population growth rate in Central Province probably because of the booming agricultural activities. About Seventy (70) percent of the population in Mkushi district now lives in rural area whereas the urban areas have the remaining thirty percent (30). The main land use in the area under consideration is agriculture with main crops cultivated being wheat, maize and soya beans. Livestock reared include cattle, goats, chickens, pigs and sheep. Much of the land in Mkushi is arable land. There are many commercial farmers that have cleared huge tracks of land specifically for farming.

\section{Methods and Materials}

\subsection{Data Collection}

In order to determine the reservoir storage capacity, bathymetry surveys were conducted during the period of high water flows when the reservoirs were at Full Supply Level (FSL). Bathymetry surveys were conducted using a Coden hydrographic boat mounted with a differential GPS (Figures 4 (a) (b). Field measurements also included the collection of elevation for the dam crests, spillway level, water surface elevation and downstream elevation at the time of measurement. Discharge measurements were carried out using a current meter on the streams at the intake of each study reservoir during the period of high flows in order to estimate suspended sediment transport. Water samples were collected at the point of discharge measurement and tested for Total Dissolved Solids (TDS) and Total Suspended Solids (TSS). Analysis of the collected data was done in the field and at the Environmental Laboratory of the University of Zambia in Lusaka.

(a)

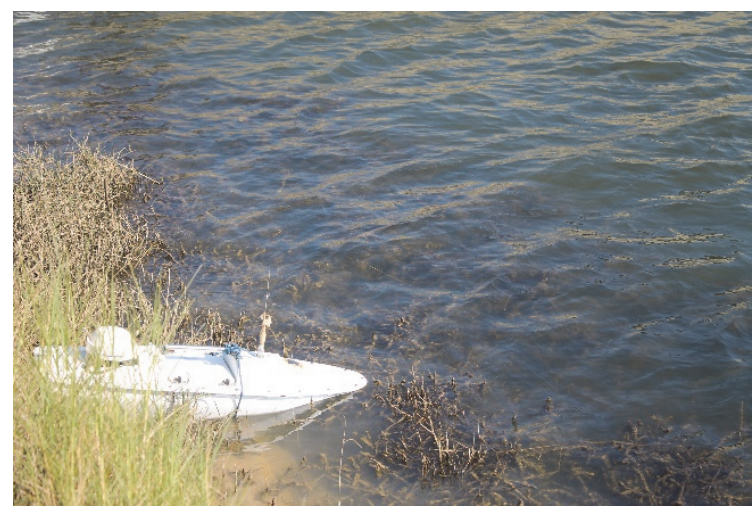

(b)

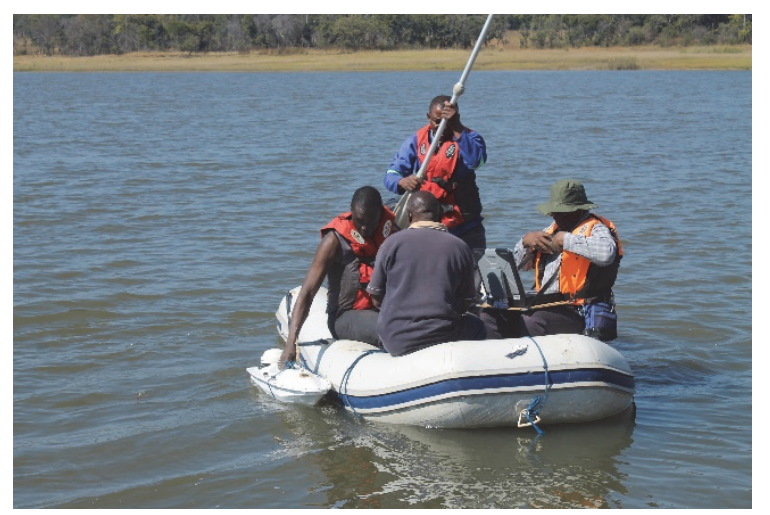

Figure 4. Photos showing (a) Hydrographic Survey boat before being launched, (b) Bathymentry Survey of Moffat Dam, $2^{\text {nd }}$ July, 2018

Discharge measurements were carried out using a current meter on the streams at the intake of each study reservoir during the period of high flows in order to estimate suspended sediment transport. Water samples were collected at the point of discharge measurement and tested for Total Dissolved Solids (TDS) and Total Suspended Solids (TSS). Analysis of the collected data was done in the field and at the Environmental Laboratory of the University of Zambia in Lusaka.

\subsection{Data Analysis}

\subsubsection{Estimation of Current Reservoir Storage Capacity}

To determine the current reservoir storage capacities, the data collected from the bathymetry surveys of the reservoirs was analysed using Surfer 15 which is a powerful contouring, gridding and surface mapping software. Surfer was instrumental in the interpolation of the XYZ data to a grid suitable for the calculation of volume, area and depth. The other data that was taken into consideration was elevation and geographical location of the 
reservoir's spillway, crest and downstream level. The spillway height of the reservoirs was set as zero.

Surfer was instrumental in screening the bathymetry data by removing repeated points and adding points. In cases where the echo-sounder did not receive strong signal, but the software still registered points, this resulted in a series of points with the same z-values. Surfer was then used to create contours of the water surface area.

Arc GIS 10.3 was used to create a polygon for each study reservoir. The reservoir polygon was drawn from a Landsat 5 image and saved in a BLN vector file format. The maximum reservoir surface water area was determined by using Landsat 5 images that were taken when the reservoirs were completely full. The Landsat 5 images consisted of 7 bands with different wavelengths. The used band combination was 432 . This combination gave a clear view of the land-water boundaries. The created BLN vector file containing the reservoir polygon was then added to the grids. To calculate the reservoir volume the Grids| Calculate |Volume button was clicked on (Golden Software (2017). Since volume is calculated between two surfaces, in the Lower Surface section, the XYZ data for a particular reservoir was browsed from its saved location and then added.

The maximum surface water area extracted from the field measurements and Landsat 5 images was used as breakline. This meant that a polygon was added with the Z-values of 0 . When the gridding algorithm sees a breakline, it calculates the Z-value of the nearest point along the breakline, and uses that value in combination with nearby data points to calculate the grid node value. To eliminate the irrelevant values outside the maximum area, a blank grid is created using Surfer's blank function. To calculate the volume of a reservoir, a base map containing the reservoir polygon was chosen from the polygon boundary section. After selecting the reservoir polygon, the "Volume Inside" provision was clicked on to calculate the volume for the reservoir polygons on the map layer (Golden Software (2017). Finally, a Grid Volume computations report was generated for the reservoir.

The calculated reservoir capacity values were then compared with the originally calculated designed capacity values to find out changes in reservoir storage capacity. Then an estimation of capacity (volume) loss due to sedimentation was made using Adwibi, Amegashie, Agyare, Tamene, Oda, Quansah \& Vlek (2009) formula:

$$
S V=R S C \text { initial }-R S C \text { initial }+n
$$

Where: $\mathrm{SV}=$ Sedimentation Volume $\left(\mathrm{m}^{3}\right)$; RSC initial = Reservoir Storage Capacity at initial year $\left(\mathrm{m}^{3}\right)$. The initial (i) year is the reservoir storage capacity at construction of the dam and the storage capacity $n$ years after the initial (i) year is the study measured storage capacity.

\subsubsection{Estimation of Suspended Sediment Transport}

To estimate suspended sediment transport in the reservoirs, the water samples collected at the intake of the reservoir were analysed for Total Suspended Solids (TSS) and Total Dissolved Solids (TDS). The water from the sediment samples was filtered, and the sediment was dried and weighted. Discharge measurements were conducted at the intake of each study reservoir. The annual rate of suspended sediment transport in to the reservoir was estimated by measuring the actual amount of suspended sediment contained in the water which entered the reservoir at the intake.

\subsubsection{Estimation of Current Rate of Sedimentation}

The rate of sedimentation per year was estimated by dividing the number of years the reservoir has been in operation into the volume of deposited sediment using equation 2 provided by Aynekulu, Atakliti,\& Ejersa (2007).

$$
\mathrm{SR}=\mathrm{SV} / \mathrm{Y}
$$

Where: SR is rate of sedimentation $\left(\mathrm{m}^{3} \mathrm{y}^{-1}\right)$; SV is Sediment Volume $\left(\mathrm{m}^{3}\right)$ and $\mathrm{Y}$ is age of reservoir (year)

The sediment volume accumulated for the period a particular reservoir was constructed and became operational was divided by the number of years a reservoir had been in existence.

\subsubsection{Elevation Change Method used in Sediment Volume Calculation}

In order to have a better understanding of the Sediment Volume computed using bathymetric data, the Elevation Change Method (ECM) of differencing bed elevation at construction was used. The first step involved collecting Surface water elevation and downstream elevation of each reservoir. The elevation data was useful in determining maximum depth near the reservoir crest. The study made use of equation 3 devised by Muchanga (2017) adapted from Sawunyama (2005) study. The method proved useful in the quick analysis of sedimentation volume in the reservoirs.

$$
S V=A \text { Wse }-D s e)-M w d / 3
$$

Where: SV= Sediment Volume; Wse $=$ Water Surface Elevation $(\mathrm{m})$; Dse = Downstream Elevation $(\mathrm{m})$; Mwd= 
Maximum Water Depth near the Crest (m); 3 = Constant derived by Sawunyama (2005); A = Total Surface Area of the Bed $\left(\mathrm{m}^{2}\right)$.

It is important to note that constants differ for the equation because of different study areas and climatic conditions and methods used to estimate surface areas, that is, from topographical maps or field surveys (Sawunyama, 2005).

\subsubsection{Estimation of future Rate of Sedimentation}

The future rate of reservoir sedimentation is also referred to as the Life Expectancy (L.E) of the reservoir. Therefore, the future rate of sedimentation is the estimated time for the reservoir to survive from the time reservoir operations started to the day it will completely be filled with sediments and thereby rendering it ineffective for water storage. Therefore using the current rate of sedimentation that was determined above and using equation 4 , the expected reservoir life was determined by dividing the designed reservoir capacity by rate of sedimentation (Aynekulu et al. 2006).

$$
L E=R S C / S R
$$

LE is the life expectancy of the reservoir (years); SR is rate of sedimentation $\left(\mathrm{m}^{3} \mathrm{y}^{-1}\right), \mathrm{RSC}$ is the reservoir storage capacity (dead) $\left(\mathrm{m}^{3}\right)$.

\section{Results}

Results for Moffat dam and GRZ Weir sedimentation assessment are presented below under the following subheadings: measured reservoir storage capacity, rate of suspended sediment transport into the reservoirs, loss of storage capacity and the future sedimentation rates.

\subsection{Measurement of Storage Capacities of Reservoirs}

The details of the measurements of the storage capacity of each reservoir and other vital information are presented in this section.

\subsubsection{Moffat Dam}

The Moffat earth dam was constructed sixteen (16) years ago in the year 2002 and had a designed storage capacity of $1,404,251 \mathrm{~m}^{3}$ with a catchment area of $42.5 \mathrm{~km}^{2}$. At the time of the bathymetry survey the water surface elevation was at $1337.73 \mathrm{~m}$ above sea level.

Table 1. Reservoir Surface Area and Volume at different depths of Moffat dam, $2^{\text {nd }}$ July 2018.

\begin{tabular}{llll}
\hline Depth (m) & Surface Area $\left(\mathbf{m}^{\mathbf{2}}\right)$ & Volume & $\left.\mathbf{( m}^{3}\right)$ \\
\hline 0 & 0 & 0 & \\
0.5 & 109,478 & 196,732 & \\
1 & 194,147 & 386,920 & \\
1.5 & 255,740 & 562,036 & \\
2 & 298,814 & 717,182 & \\
2.5 & 333,575 & 838,333 & \\
3 & 349,692 & 914,220 & \\
3.5 & 368,395 & 965,220 \\
4 & 383,869 & 998,046 \\
4.5 & 397,071 & $1,049,021$ \\
5 & 411,308 & $1,089,321$ \\
5.5 & 435,865 & $1,180,462$ \\
\hline
\end{tabular}

The water depth of Moffat reservoir ranged from $-0.38 \mathrm{~m}$ to $-5.74 \mathrm{~m}$ with half of the reservoir depth occurring at $-1.59 \mathrm{~m}$. Figure 5 shows bathymetry survey path line results recorded during the survey (a) superimposed on Google earth image while (b) provides location details. The bathymetric map is shown in Figure 6. 


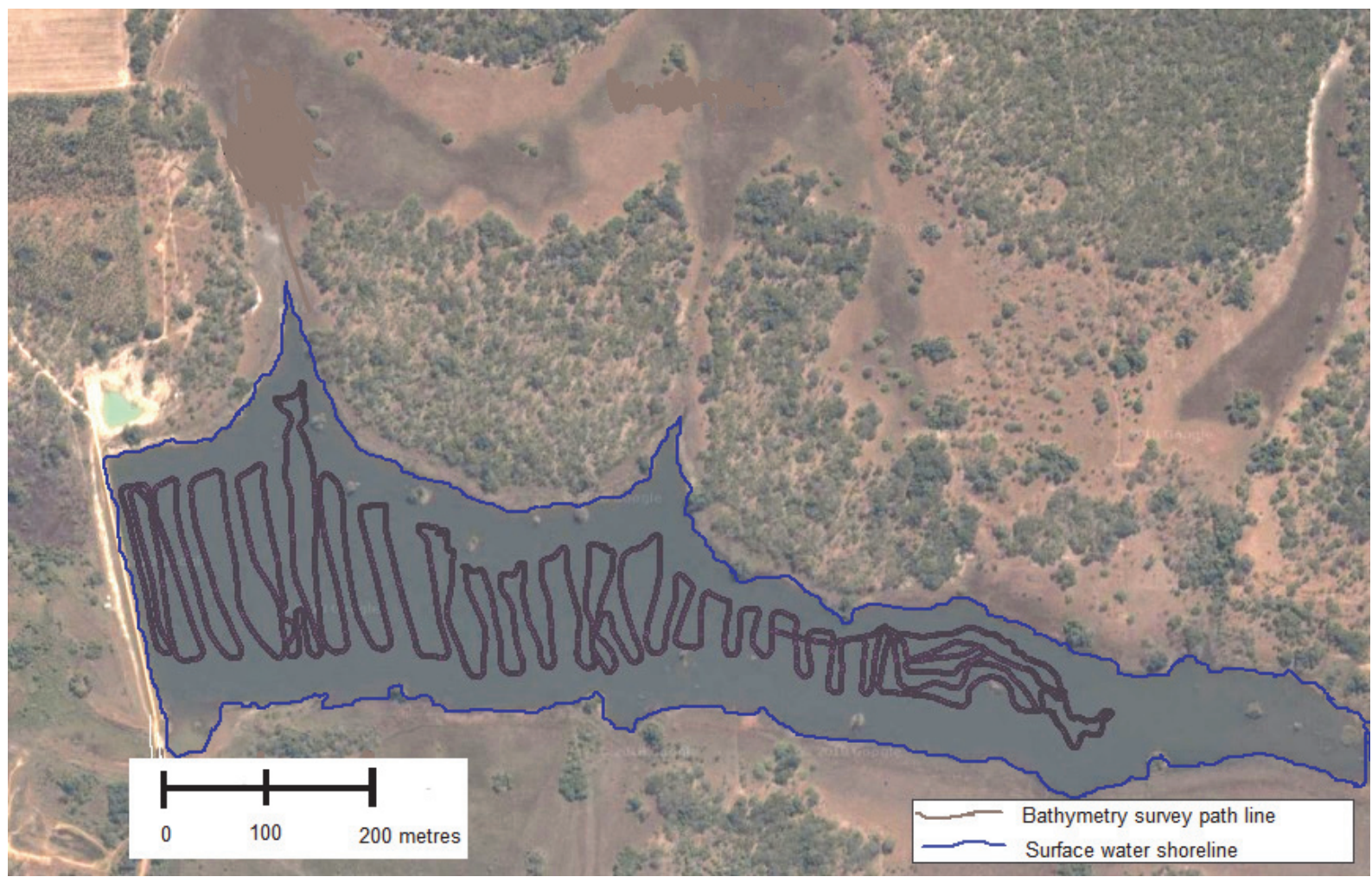

Figure 5. Maps showing bathymetry survey path lines on Moffat dam superimposed on Google satellite image ( $2^{\text {nd }}$ July, 2018)

The water surface area for Moffat dam was found to be $435,865 \mathrm{~m}^{2}$ with a water volume of $1,180,462 \mathrm{~m}^{3}$ (Table 1). The generated hypsometric curves show close relationships between water depth and reservoir volume (Figures 7a), depth and surface area (Figure 7b) and between reservoir surface area and reservoir volume (Figure 7c). The reservoir's current storage capacity was found to be $1,180,462 \mathrm{~m}^{3}$ which was slightly lower than 1,404,251 $\mathrm{m}^{3}$, the storage capacity at construction in the year 2002. This indicates that sediment deposition between 2002 and 2018 in Moffat dam has resulted in a loss of approximately 223,789 $\mathrm{m}^{3}(16 \%)$ of the initial storage capacity of $1,404,251 \mathrm{~m}^{3}$. Summary results for Moffat dam are provided in Table 2.

(a)

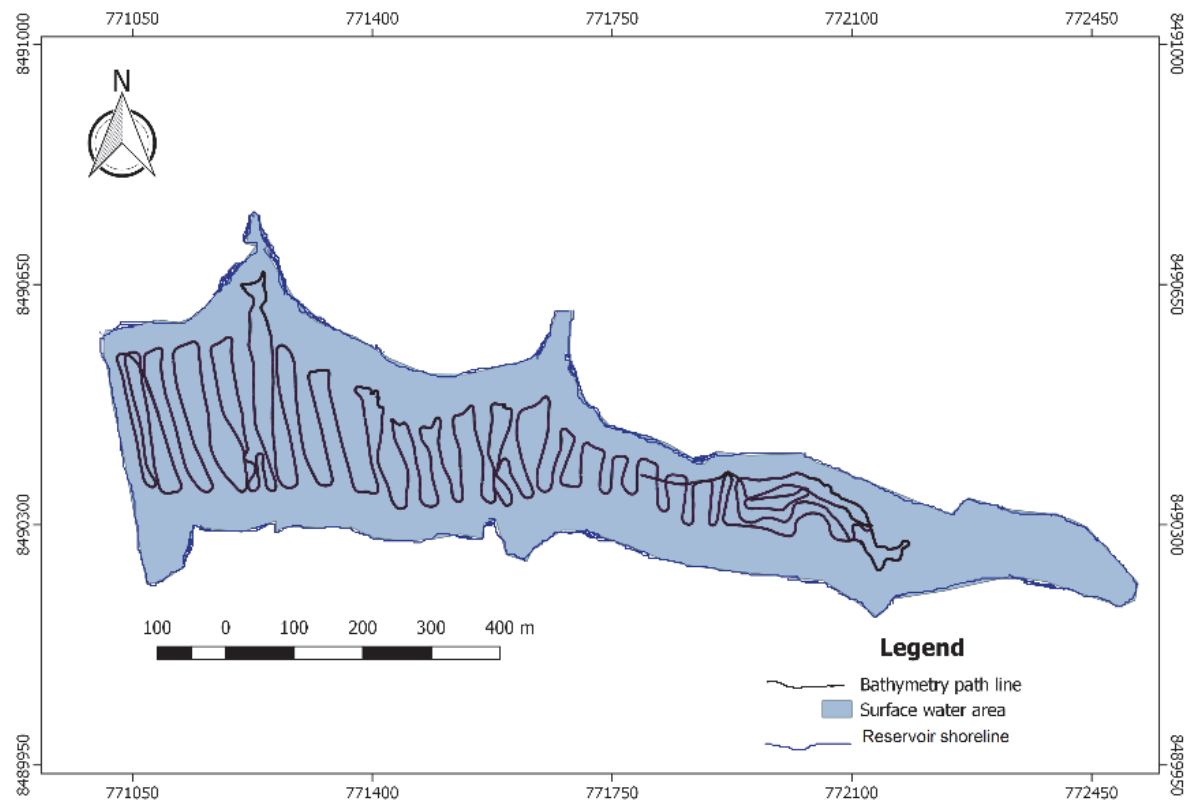


(b)

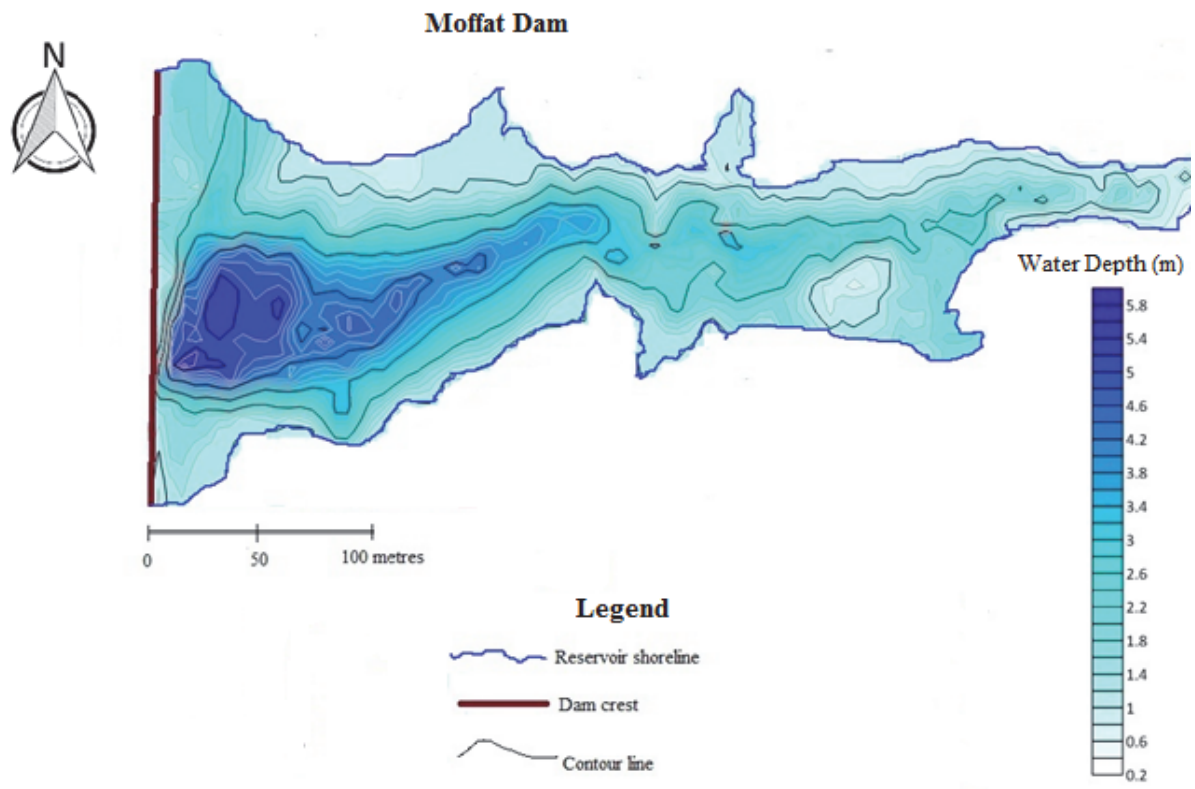

Figure 6. Bathymetry maps showing (a) survey path line on water surface area with location details and (b)

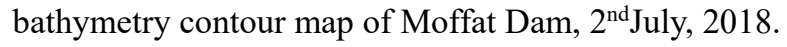

(a)

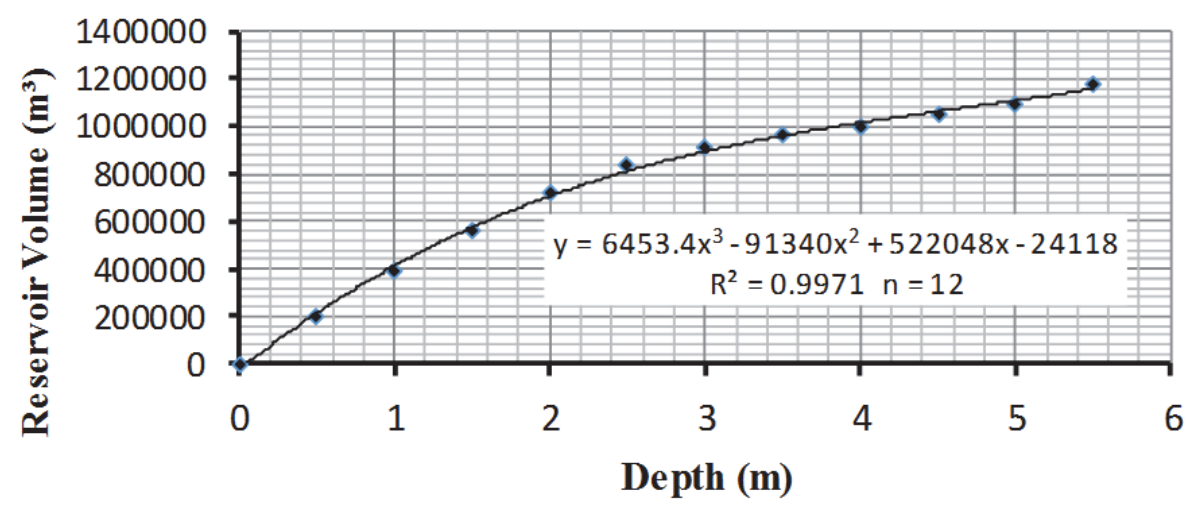

(b)

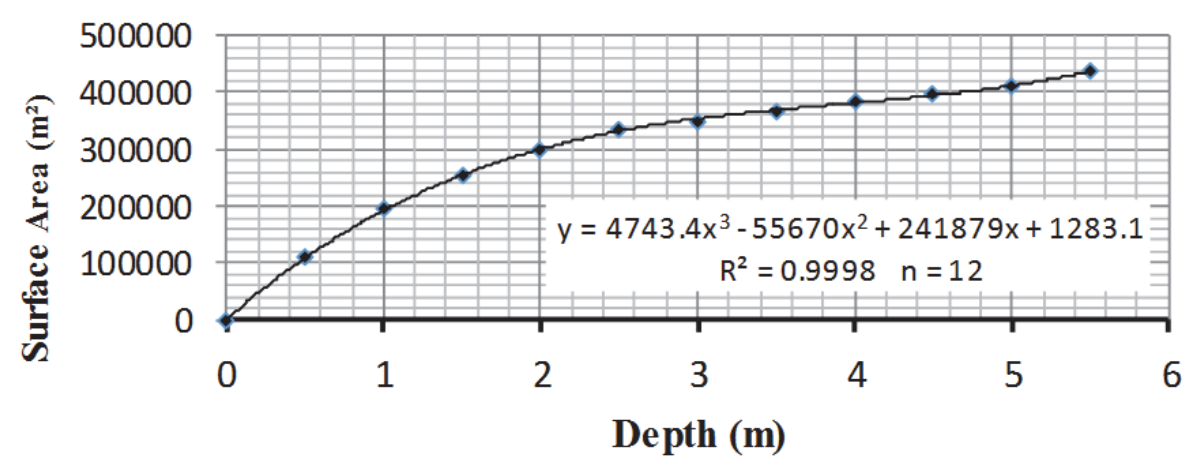


(c)

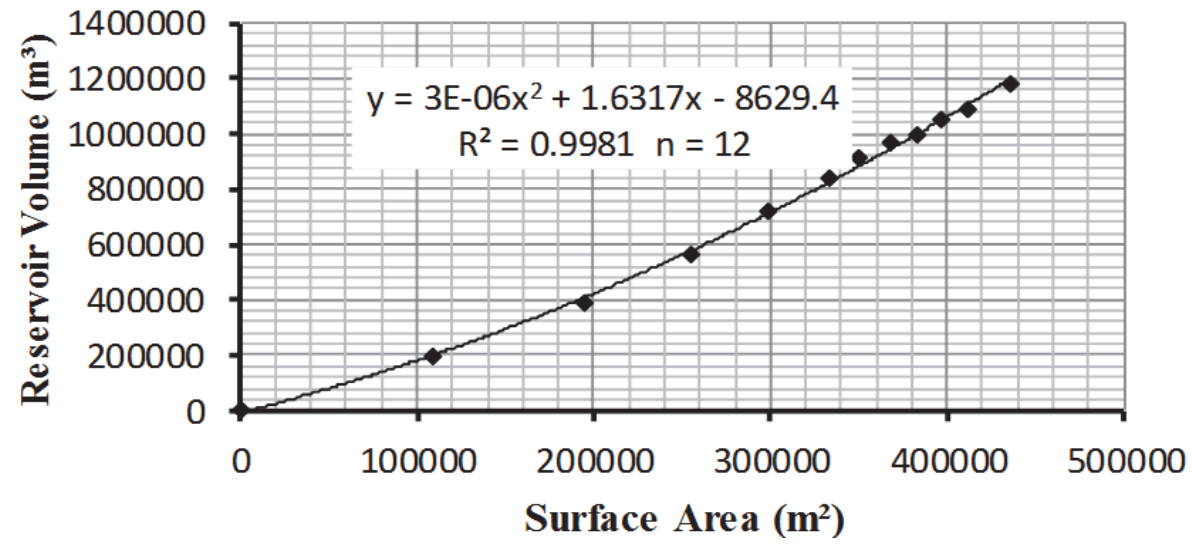

Figure 7. Hypsometric graphs showing (a) Depth-Volume (b) Depth-Area and (c) Area-Volume relationships for Moffat dam

Table 2. Summary of Storage Capacity and Sediment Statistics for Moffat dam and GRZ Weir

\begin{tabular}{|c|c|c|c|c|c|c|c|c|}
\hline $\mathrm{S} / \mathrm{N}$ & $\begin{array}{l}\text { Reservoir } \\
\text { Name }\end{array}$ & $\begin{array}{l}\text { Year } \\
\text { Constructed }\end{array}$ & $\begin{array}{l}\text { Measured } \\
\text { Water Surface } \\
\text { Area }\left(\mathrm{km}^{2}\right)\end{array}$ & $\begin{array}{l}\text { Storage Capacity } \\
\text { at Construction } \\
\left(\mathrm{m}^{3}\right)\end{array}$ & $\begin{array}{l}\text { Measured } \\
\text { Reservoir } \\
\text { Storage } \\
\text { Capacity } \\
\end{array}$ & $\begin{array}{l}\text { Estimated } \\
\text { Sediment } \\
\text { Volume } \\
\left(\mathrm{m}^{3}\right) \\
\end{array}$ & $\begin{array}{l}\text { Estimated } \\
\text { mean } \\
\text { Sediment } \\
\text { Depth }(\mathrm{m}) \\
\end{array}$ & $\begin{array}{l}\text { Estimated } \\
\text { Annual Rate of } \\
\text { Sedimentation } \\
\left(\mathrm{m}^{3} \mathrm{yr}^{-1}\right)\end{array}$ \\
\hline 1 & Moffat & 2002 & 435,865 & $1,404,251$ & $1,180,462$ & 223,789 & 2.01 & $13,986.81$ \\
\hline 2 & GRZ Weir & 1982 & $88,661.46$ & 250,530 & 197,218 & 53,312 & 1.71 & $1,480.89$ \\
\hline
\end{tabular}

\subsubsection{GRZ Weir}

The GRZ Weir which was constructed thirty-six (36) years ago in the year 1982 had a designed storage capacity of $250,530 \mathrm{~m}^{3}$ with a catchment area of $25.4 \mathrm{~km}^{2}$. At the time of the bathymetry survey its water surface elevation was at $1305.222 \mathrm{~m}$ above sea level. The water depth of the GRZ Weir ranged from $-0.63 \mathrm{~m}$ to $-5.2 \mathrm{~m}$ with half of the reservoir depth occurring at $-1.49 \mathrm{~m}$ (Table 3). Figures 8 a shows field record results as map overlay on Google earth image while Figure $8 \mathrm{~b}$ shows the GIS mapped bathymetry survey path line while Figure 9 provides the bathymetric map. The water surface area for GRZ Weir was found to be $88,661.46 \mathrm{~m}^{2}$ with a water volume of $197,218 \mathrm{~m}^{3}$ (Table 3). The generated hypsometric curves show very close relationship between water depth and reservoir volume (Figures 10a), depth and surface area (Figure 10b) and between reservoir surface area and reservoir volume (Figure 10c). The reservoir's current storage capacity found to be $197,218 \mathrm{~m}^{3}$ was slightly lower than $250,530 \mathrm{~m}^{3}$ the storage capacity at construction in the year 2002. This indicates that sediment deposition between 1982 and 2018 in the GRZ Weir has resulted in a loss of approximately 53,312 $\mathrm{m}^{3}(21.3 \%)$ of the initial storage capacity of $250,530 \mathrm{~m}^{3}$. Table 3 provides a summary of GRZ Weir statistics.

Table 3. Reservoir Surface Area and Volume at different depths of GRZ Weir, $4^{\text {th }}$ July 2018

\begin{tabular}{lll}
\hline $\begin{array}{l}\text { Depth } \\
(\mathbf{m})\end{array}$ & $\begin{array}{l}\text { Surface Area } \\
\left(\mathbf{m}^{\mathbf{2}}\right)\end{array}$ & $\begin{array}{l}\text { Volume } \\
\left(\mathbf{m}^{\mathbf{3}}\right)\end{array}$ \\
\hline 0 & 0 & 0 \\
0.5 & 3,900 & 10,263 \\
1 & 20,715 & 49,441 \\
1.5 & 44,629 & 99,216 \\
2 & 62,857 & 136,799 \\
2.5 & 75,795 & 164,689 \\
3 & 81,567 & 178,239 \\
3.5 & 84,076 & 186,733 \\
4 & 86,523 & 194,512 \\
4.5 & 88,049 & 196,849 \\
\hline
\end{tabular}




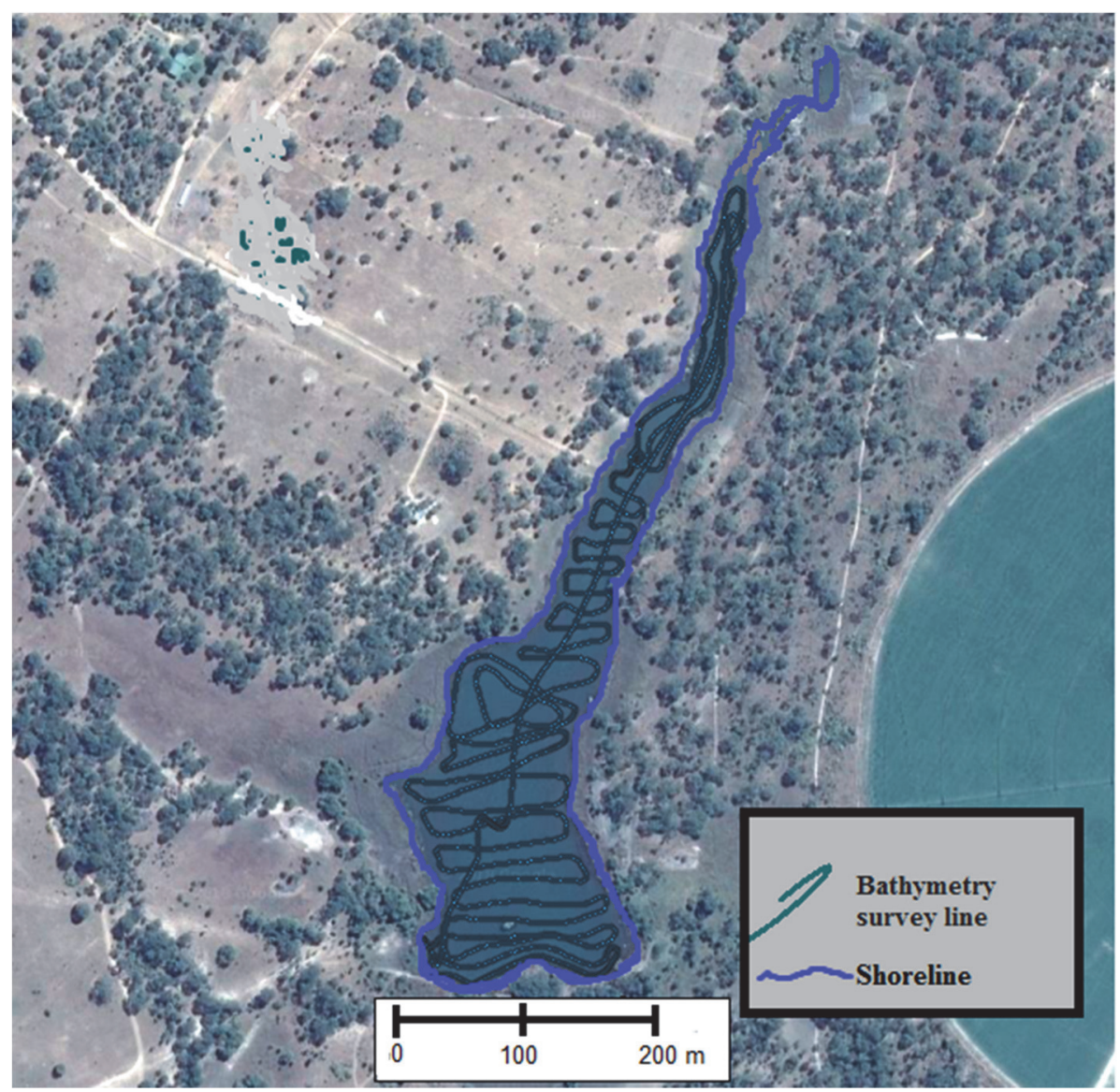

Figure 8. Google earth satellite image with superimposed bathymetry survey path line of GRZ Weir, $4^{\text {th }}$ July, 2018

(a)

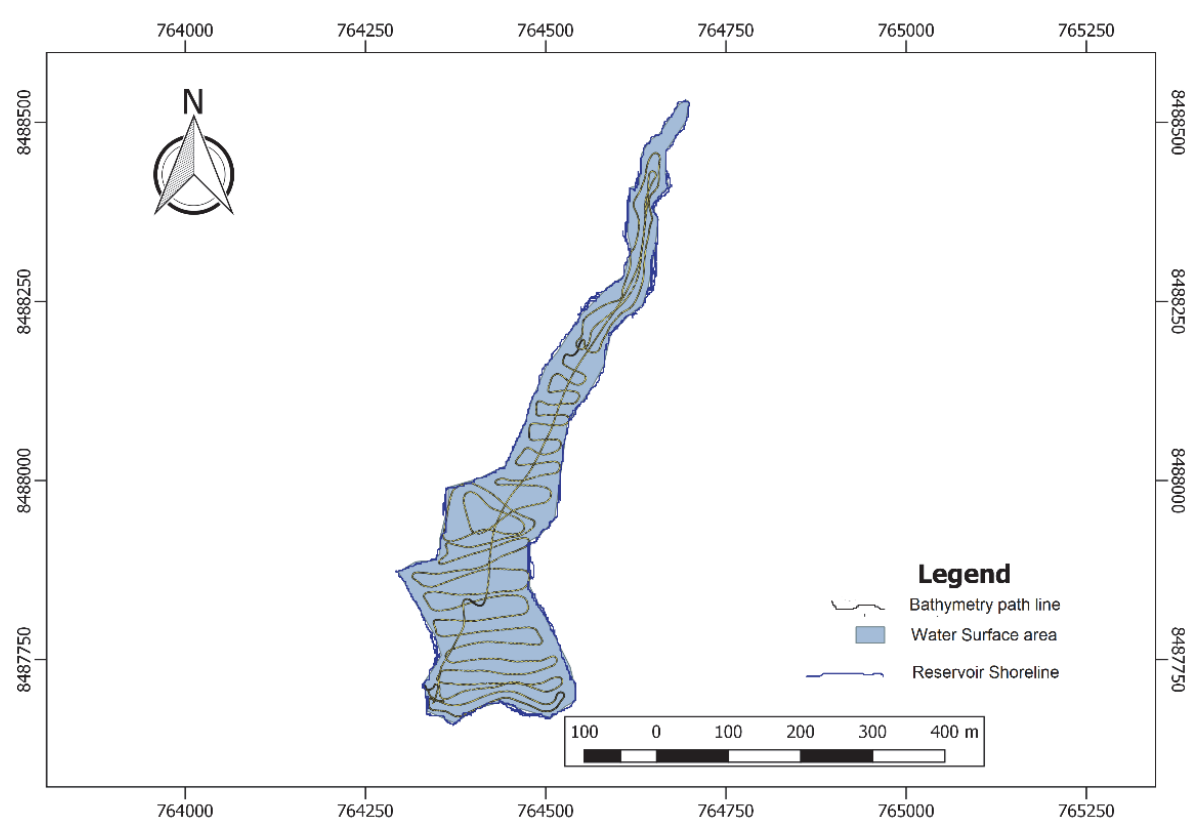


(b)

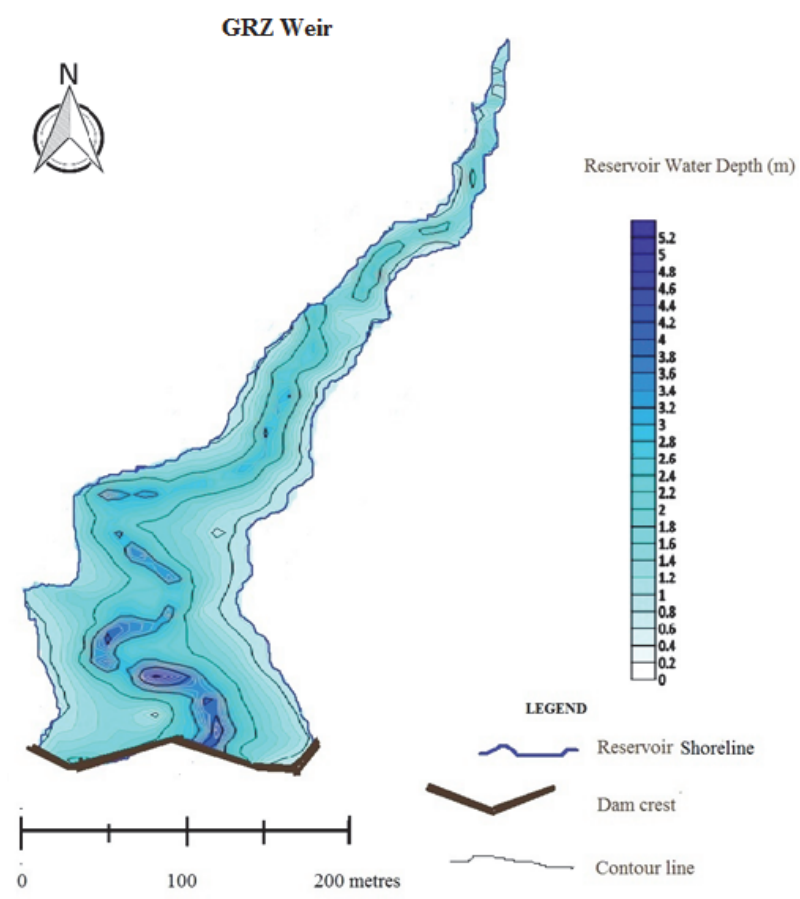

Figure 9. Bathymetry maps showing (a) survey path line on water surface area with location details and (b) bathymetry contour map of GRZ Weir, $4^{\text {th } J u l y, ~} 2018$

(a)

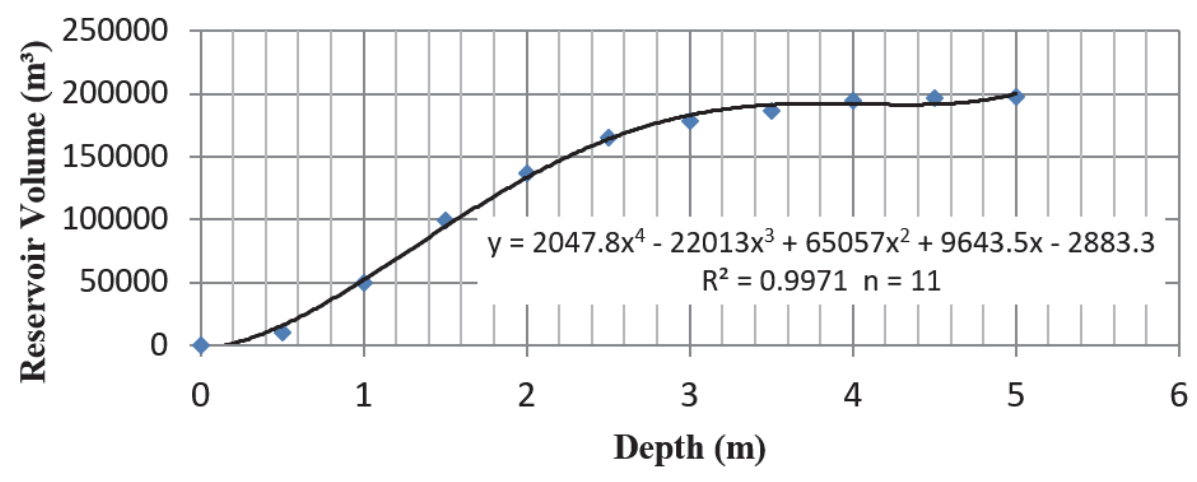

(b)

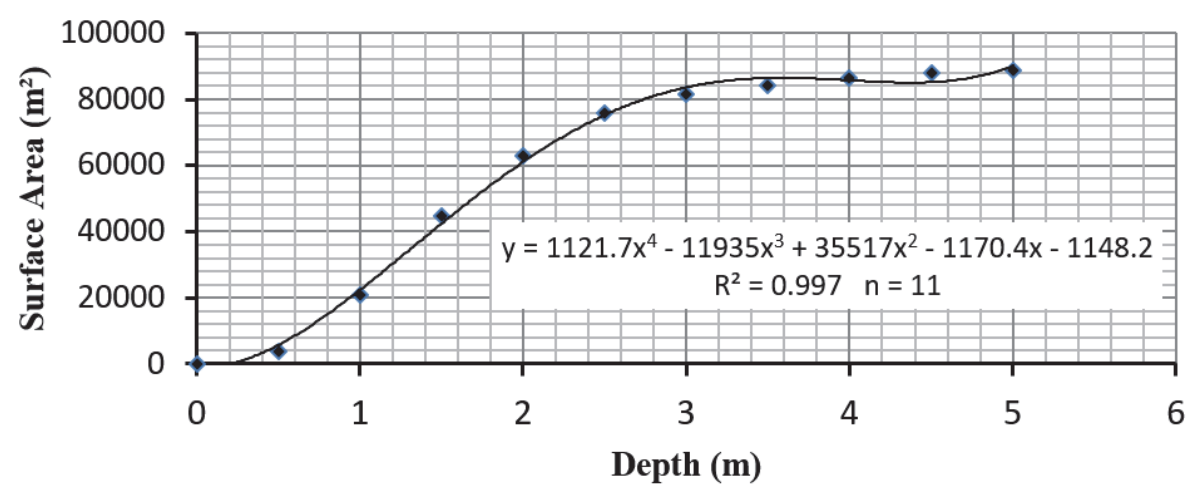


(c)

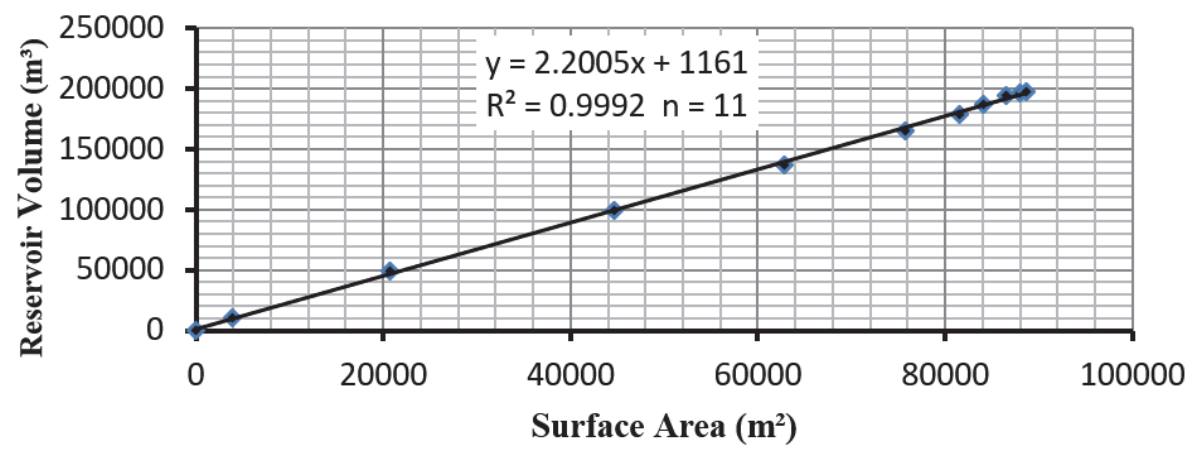

Figure 10. Hypsometric graphs showing (a) Depth-Volume (b) Depth-Area relationships and (c) Area-Volume Relationship for GRZ Weir, $4^{\text {th }}$ July, 2018

\subsection{Rate of Suspended Sediment Transport}

The rate of suspended sediment transport in to the reservoir was calculated using the results from TSS and discharge measurements conducted at the intake of each of the two dams. The discharge for Moffat dam was estimated at $0.047 \mathrm{~m}^{3} / \mathrm{s}$ and GRZ Weir had $0.076 \mathrm{~m}^{3} / \mathrm{s}$. Analysis of the water samples revealed that, Moffat's dam had TSS of $0.4 \mathrm{mg} / 1$ while the GRZ Weir had $0.6 \mathrm{mg} / \mathrm{l}$. The annual rate of suspended sediment transport into Moffat dam was estimated at 59.3 tonnes while that for the GRZ Weir was at 143.8 tonnes.

\subsection{Determination of the Rate of Sedimentation in the Study Reservoirs}

Having estimated the storage capacity loss for Moffat dam in 16 years at 223,789 $\mathrm{m}^{3}$ and 53,312 $\mathrm{m}^{3}$ for GRZ Weir in 36 years, Table 4.2 shows the rate of sedimentation loss for Moffat reservoir was found to be $13,986.81 \mathrm{~m}^{3} \mathrm{yr}^{-1}$ with a lifespan of 84 years while that of the GRZ Weir was found to be $1,480.89 \mathrm{~m}^{3} \mathrm{yr}^{-1}$ with a lifespan of 133 years.

\section{Discussion}

This study has revealed the current reservoir storage capacities, reservoir storage loss, sediment volumes and rate of sedimentation of two reservoirs in central Zambia. The findings accords well with results reported elsewhere in Zambia and other parts of Africa.

\subsection{Reservoir Storage Capacity}

The studied reservoirs on the Mushibemba catchment have lost a small amount of storage capacity to sedimentation. The reservoir storage capacity losses observed in Moffat dam and the GRZ Weir ranged from 16 percent to 21.3 percent agreeing with Chao (2004) findings that showed that 1 percent of the precious storage capacity of the world's reservoirs is annually lost due to river related sedimentation. When the study findings were compared with the results of the small dams in Lusaka studied by Chomba \& Sichingabula (2015), it was noted that the reservoirs had lost a substantial amount of storage capacity ranging from 49 percent and 50 percent, which is much higher than what was found in this study. Meanwhile, when the study findings were further compared with the results of the sedimentation study of Makoye reservoir in Southern province of Zambia by Muchanga (2017), it was found that there was a reservoir storage capacity loss of 53.5 percent. The results of the storage capacity loss for the Makoye reservoir which was constructed in 1940 were much higher especially that the reservoir had been dredged in 1988.

When a quick sedimentation volume assessment was made using the mean bed elevation measurements of each reservoir by differencing it with downstream elevation taken as the assumed elevation at the time of reservoir construction, the results were found to be closely related to those of the bathymetry survey (Muchinga, 2017). The calculated mean bed depth for Moffat dam was $2.01 \mathrm{~m}$ while that of the GRZ Weir was $1.71 \mathrm{~m}$. The reservoir storage capacity loss for Moffat dam using the mean bed elevation method was found to be $292,030 \mathrm{~m}^{3}$ while that of the GRZ Weir was calculated as $50,537 \mathrm{~m}^{3}$. Meanwhile, the bathymetry method using the hydrographic survey boat estimated the storage capacity loss for Moffat dam at 223,789 $\mathrm{m}^{3}$ in 16 years while that of GRZ Weir in 36 years was $53,312 \mathrm{~m}^{3}$. The results obtained from the above sedimentation assessment shows that the Elevation Change Method results are closely related to the hydrographic survey method which is more reliable. 
The 16 percent reservoir storage capacity loss for Moffat dam is of great concern. The designed storage capacity for Moffat dam was highly affected by alteration of the reservoir structure. Satellite images observed show that before the year 2002 there existed a small reservoir on Moffat dam whose embankment was later erased to make one reservoir with the newly constructed dam. Therefore, there is high probability that the reservoir storage capacity was altered.

Secondly, Moffat dam is located at the bottom of a gentle slope of between 2-5 percent (1.1 to 3 degrees) where the inflow into the reservoir drops in the velocity and turbulence of the water thereby reducing the potential to erode the river channel. Moffat dam catchment and banks have a very good vegetation cover comprising of tall trees upstream followed by grassland and wetland areas on the bank of the river and reservoirs thereby impeding the fast erosion and transportation of sediment (see Figure 5). The GRZ Weir had a lower storage capacity loss than Moffat dam because of its smaller water surface area and catchment (Table 2). The GRZ Weir's catchment area of $24.5 \mathrm{Km}^{2}$ is smaller than that of Moffat dam estimated at $42.5 \mathrm{Km}^{2}$.

\subsection{Rate of Sedimentation}

The two studied reservoirs had low amounts of deposited sediment. Moffat dam had the highest amount of deposited sediment of $223,789 \mathrm{~m}^{3}$, followed by GRZ Weir with $53,312 \mathrm{~m}^{3}$. However, the rate of sedimentation for Moffat dam $\left(13,986.81 \mathrm{~m}^{3} \mathrm{yr}^{-1}\right)$ was higher than that of GRZ Weir $\left(1,480.89 \mathrm{~m}^{3} \mathrm{yr}^{-1}\right)$ because of the differences in catchment characteristics. Moffat dam had a higher rate of sediment than the GRZ Weir because of its huge water surface area and a catchment with large cultivated areas.

The results of the rates of sedimentation obtained for the GRZ Weir were below the order of magnitude as those observed by Aynekulu et al, (2007) in the study conducted in Tigray, northern Ethiopia, where the annual rate of sedimentation of Filiglig and Grashito reservoirs were found to be $6,928 \mathrm{~m}^{3} \mathrm{yr}^{-1}$ and $11,987 \mathrm{~m}^{3} \mathrm{yr}^{-1}$, respectively. However, the sedimentation rate for Moffat dam was slightly higher than that of the Ethiopian study mentioned above. When the study findings were further compared with the results of the four dams studied by Chomba \& Sichingabula (2015), it was found that two dams, namely, Katondwe $\left(283.9 \mathrm{~m}^{3} \mathrm{y} \mathrm{r}^{-1}\right)$ and Morester $\left(251 \mathrm{~m}^{3} \mathrm{yr}^{-1}\right)$ had annual rates of sedimentation that were lower than that of GRZ Weir $\left(\left(1,480.89 \mathrm{~m}^{3} \mathrm{yr}^{-1}\right)\right.$. Meanwhile Moffat dam had an annual rate of sedimentation that was slightly lower than Silverest dam with $14,595.4 \mathrm{~m}^{3} \mathrm{yr}^{-1}$. On the other hand, findings by Muchanga (2017) study found the annual rate of sedimentation to be 3,112.969 $\mathrm{m}^{3} \mathrm{yr}^{-1} \mathrm{a}$ figure which is lower than the results for Moffat dam and higher than the results of GRZ Weir.

The differences in sedimentation rates among these dams can be attributed to the differences in catchment characteristics. Moffat dam had a higher rate of sediment than the GRZ Weir because of its huge surface area and catchment. However, in terms of the amount of sediment transported, GRZ Weir had more sediment conveyed than Moffat dam because it was surrounded by a vast agricultural land. Moffat dam had a well-managed forest with abundant trees and grassland. According to Queensland Government (2006), over clearing of catchments and stream bank vegetation; poorly managed sand and gravel extraction; and stream straightening works are some of the examples of poor land management practices which result in accelerated rates of bank erosion which eventually leads to reservoir sedimentation when the eroded material is deposited in the reservoirs. In the case of the commercial farmers in the Moffat dam and GRZ Weir catchments, it will be observed that they have huge tracts of land, therefore it is very easy for them to develop good land management practices which reduce the rate of sedimentation. Bathymetry survey and sedimentation assessment of the Mushibemba reservoirs were important because they helped to provide information on the soil erosion and sedimentation related problems in the catchment. The results of the study will help the farmers around the GRZ Weir to come up with appropriate land cultivation techniques that will prevent the generation and transportation of more sediment that is transported into reservoirs.

\subsection{Suspended Sediment Transport}

When the TSS results for Moffat's dam $(0.4 \mathrm{mg} / \mathrm{l})$ and GRZ Weir $(0.6 \mathrm{mg} / \mathrm{l})$ were compared with Chomba \& Sichingabula (2015) findings estimated at $1 \mathrm{mg} / \mathrm{l}$ for each of the four reservoirs, it was noted that the rate of suspended sediment transport for this study was not very high. When the same results were compared with Muchanga (2017) sedimentation study findings on Makoye reservoir, it was observed that the TSS results of 3,100 $\mathrm{mg} / \mathrm{l}$ was by far very high. When we focus on the annual rate of suspended sediment transport into Moffat dam (59.3 tonnes) and GRZ Weir (143.8 tonnes) and relate with that of Muchanga (2017) study, it was observed that Makoye reservoir with 6,145.589 tonnes had by far more sediment transported in to the reservoir. When the above results were compared with similar studies conducted by Walling, Sichingabula \& Leeks (2001) in the Upper Kaleya River of Southern Province, it was estimated that the daily suspended sediment loads in the catchment ranged from 0 to 253.9 tonnes, with a daily mean of 3.15 tonnes. Most of this sediment load was transported during 
flood events, which occurred in a few days of each year. Sediment delivered to reservoirs originates from a number of upstream primary and secondary sediment sources, including cultivated fields and stream bank erosion (Collins, Wallings \& Leeks, 1997).

\subsection{Reservoir Sedimentation}

When the calculated life expectancy of Moffat dam (84 years) and GRZ Weir (133 years) were compared with the results of other reservoir sedimentation studies conducted in Zambia, it was found that the reservoirs of Mushibemba Catchment had a much longer lifespan. For instance, Chomba \& Sichingabula (2015) found the lifespan of their four studied reservoirs to be as follows: 26 years for Silverest dam; 46 years for Lwimba; 38 years for Katondwe and 58 years for Morester dam. Meanwhile, most recently, Muchanga (2017) estimated the lifespan of Makoye reservoir to be 24 years. One of the reasons why Moffat dam and GRZ Weir have a longer lifespan is because their catchments have very good land management practices which reduce the rate of sedimentation. The reservoir catchments do not experience river bank cultivation and erosion. There is controlled grazing which has led to continued good vegetation cover.

\section{Conclusion}

Despite observing that the reservoir storage capacity losses and annual sediment transport for Moffat dam and GRZ Weir were lower than the results of studies conducted in other parts of Zambia, the study concluded that sedimentation in the Mushibemba Catchment was fairly serious given reservoir capacity losses observed due to agricultural activities despite having very good vegetation cover. It was further concluded that suspended sediment in the two reservoirs mainly originated from the cleared commercial agricultural land upstream which predominantly consists of clayey to loamy soils. This also accounted for the high turbidity of the reservoir water. This situation therefore calls for periodic reservoir assessment of sedimentation and dredging of the deposited sediment to increase storage capacity.

\section{Acknowledgements}

The Authors acknowledge the financial support provided by the World Bank through the Zambia Water Resources Development Project (ZWRDP), Project Funding No. P114949 in the Ministry of Water Development, Sanitation and Environmental Protection (MWDSEP). We also appreciate the technical assistance given to us in the field by Mr. Happy Sikazwe and staff from the Water Resources Management Authority (WARMA).

\section{References}

Adwubi, A., Amegashie, B. K., Agyare, W. A., Tamene L., Odai, S. N., Quansah, C., \& Vlek, P. (2009). Assessing sediment inputs to small reservoirs in Upper East Region, Ghana. Lakes and Reservoirs: Research and Management, 14(4), 279-287. https://doi.org/10.1111/j.1440-1770.2009.00410

Aynekulu, E., Atakliti, S., \& Ejersa, A. (2007). Small-Scale Reservoir Sedimentation Rate Analysis for a Reliable Estimation of Irrigation Schemes Economic Lifetime: (A Case Study of Adigudom Area, Tigray, Northern Ethiopia): Mekelle University, Mekelle, Ethiopia. Retrieved from http://131.220.109.9/module/register/media/6dd3_Siltation_Tigray_EthiopiaErmias

Brandani, S., Caporali, E., \& Federici, G. (2006). Monitoring Reservoir Sedimentation for Management Policy Definition: Universsita degli Studi di Firenze- Firenze (IT). Retrieved from http://www.cosis.net/abstracts/EGU06/09873/EGU06-J-09873-1

Central Statistics Office (CSO). (2010). Preliminary report on Population Census: Government printers, Lusaka.

Chao, L. (2004). Sediment problems eased at Three Gorges, China Daily. Retrieved from Retrieved from https://www.chinadaily.com.cn/english/doc/2004-10/20 content-383820

Chomba, I., \& Sichingabula, H. (2015). Sedimentation and Its Effects on Selected Small Dams East of Lusaka, Zambia. Modern Environmental Science and Engineering, 1(6), 325-340. Academic Star Publishing. https://doi.org/10.15341/mese

Collins, A. L., Walling, D. E., \& Leeks, G. J. L. (1997). Source type ascription for fluvial suspended sediment based on a quantitative composite fingerprinting technique. Technical Report, 29, 1-27. https://doi.org/10.1016/50341-8162(96)0064-1

Golden Software. (2017). How to Calculate Volume of a Reservoir in Surfer 15. Retrieved from https://www.support.goldensoftware.com/surfer

JICA. (1995). Final Report on the study of the National Water Resources Master Plan in the Republic of Zambia: Yachiyo Engineering Cooperation Limited. 
Johnson, D. L., \& Lewis, L. A. (1995). Land Degradation: Creation and Destruction. Blackwell: Oxford.

Martinko, E. A., Denoyelles, F., \& Jakubauskas, M. (2006). Comprehensive Reservoir Assessment and Monitoring, Kansas Biological Survey: University of Kansas, Lawrence. Retrieved from https://www.kars.ku.edu

Muchanga M. (2017), Understanding Sedimentation Process in the Makoye Reservoir of Southern Zambia. Journal of Geography and Earth Sciences, 5(1), 1-20. https://doi.org/10.15640/jges.v5n1a6

Queensland Government (2006). What causes bank erosion? Natural Resources and Water. Riverseries: Queensland the Smart State. Retrieved from https://www.nrw.qld.gov.au/factsheets/pdf/river/r2

Sawunyama, T. (2005). Estimation of Small Reservoir Storage Capacities in Limpopo River Basin Using Geographical information Systems (GIS) and Remotely Sensed Surface Areas: a Case of Mzingwane Catchment: University of Zimbabwe, Harare. https://doi.org/10.16/jpce.2006.08.008

Sichingabula, H. (1997). Problems of Sedimentation in Small Dams in Zambia. In D.E. Walling \& J.L. Probst (Eds), Human Impact on Erosion and Sedimentation, IAHS, Publ., 1997, No. 245, pp 251-259. https://doi.org/10.1016/j.catena.2012.07.006

Stillman, C. J. (1965). The Geology of the Musofu River and Mkushi Areas: Explanation of Degree Sheet 1329, Part of the NW Quarter and SW Quarter. Lusaka. https://doi.org/10.1016/0301-9268(77)90002-x

Walling, D. E., Collins, A. L., Sichingabula, H. M., \& Leeks, G. J. L. (2001). Integrated Assessment of Catchment Suspended Sediment Budget: A Zambian Example. Land Degradation and Development, 12, 387-415. https://doi.org/10.1002/ldr.461

WARMA. (2016). Luangwa Catchment Annual Report-2016: Water Resources Management Authority, Kabwe.

\section{Copyrights}

Copyright for this article is retained by the author(s), with first publication rights granted to the journal.

This is an open-access article distributed under the terms and conditions of the Creative Commons Attribution license (http://creativecommons.org/licenses/by/4.0/). 